\title{
Positive responses of a seagrass ecosystem to experimental nutrient enrichment
}

\author{
Brendan P. Kelaher ${ }^{1, *}$, James Van Den Broek ${ }^{2}$, Paul H. York ${ }^{2,3}$, Melanie J. Bishop ${ }^{2,4}$, \\ David J. Booth ${ }^{2}$ \\ ${ }^{1}$ National Marine Science Centre \& Centre for Coastal Biogeochemistry Research, School of Environment, \\ Science and Engineering, Southern Cross University, PO Box 4321, Coffs Harbour NSW 2450, Australia \\ ${ }^{2}$ School of the Environment, University of Technology Sydney, Broadway 2007, New South Wales, Australia \\ ${ }^{3}$ Centre for Integrative Ecology, Deakin University, Waurn Ponds 3216, Victoria, Australia \\ ${ }^{4}$ Department of Biological Sciences, Macquarie University, North Ryde 2109, New South Wales, Australia
}

\begin{abstract}
Nutrient enrichment of coastal waters is widely recognized as a major driver of seagrass decline. Under conditions where seagrasses are nutrient-limited, however, moderately elevated nutrient loads can enhance seagrass biomass and increase above- and below-ground consumers that support higher order predators. To improve understanding of bottom-up processes in seagrass ecosystems, we conducted a manipulative field experiment to simultaneously evaluate the responses of primary producers (seagrass and epiphytes) and the epiphyte- and the sedimentbased components of seagrass food webs to moderate and high levels of waterborne nutrients. Fifteen $7 \mathrm{~m}^{2}$ sites in Zostera muelleri meadows were assigned randomly to control, moderate or high nutrient treatments and were enriched with $0,1800 \mathrm{~g}$ and $3600 \mathrm{~g}$ respectively of slow-release fertilizer in above-ground dispensers. The experiment ran for 9 mo (August 2006 to April 2007) and the fertilizer was replaced every 2 mo to ensure continuous enrichment. The biomass of primary producers (seagrasses $Z$. muelleri, Halophila ovalis and associated epiphytes) and the abundance of predators in the epiphyte- and the sediment-based components of the food web were greater in nutrient-enriched treatments than in controls. Epiphyte grazers, deposit feeders/detritivores, suspension feeders and benthic grazers did not respond significantly to the nutrient enrichment. In general, responses to nutrient enrichment were similar for medium and high nutrient treatments except that the biomass and surface area of seagrass was greater in high enrichment sites. These results demonstrate that $Z$. muelleri-dominated seagrass meadows in oligotrophic systems may be resilient to greater nutrient loads. Effective conservation strategies for $Z$. muelleri meadows should continue to consider interactions among nutrient enrichment and other key anthropogenic stressors, particularly non-nutrient pollutants in runoff and sewage discharge.
\end{abstract}

KEY WORDS: Seagrass $\cdot$ Nutrient enrichment $\cdot$ Zostera $\cdot$ Halophila $\cdot$ Grazers $\cdot$ Predators

\section{INTRODUCTION}

Seagrass meadows are productive coastal ecosystems that support substantial biodiversity and provide valuable ecosystem services (Barbier et al. 2011). Seagrasses recycle nutrients (McMahon \& Walker 1998), sequester carbon (Duarte et al. 2005) and supply organic matter that underpins productive coastal food webs (Heck et al. 2008). They also stabilize sediment and reduce water flow, thereby enhancing coastal protection (Orth et al. 2006). Seagrasses provide habitat for diverse communities of marine microbes, flora and fauna (Hemminga \& Duarte 2000), and serve as a nursery for ecologically and economically important fish and invertebrates (Heck et al. 2003). 
Seagrasses and the ecosystems they support are currently in decline, with a global reduction in seagrass distribution of $29 \%$ over the last $140 \mathrm{yr}$ (Waycott et al. 2009). Although seagrass decline is undoubtedly a result of many factors (e.g. climate change, foreshore development, dredging, oil spills; Short et al. 2007), nutrient enrichment is often singled out as a primary cause (Short \& WyllieEcheverria 1996, Kenworthy et al. 2006). In eutrophic systems, there is strong experimental evidence that nutrient enrichment negatively impacts seagrass biomass (Hughes et al. 2004). Nutrients promote growth of phytoplankton and epiphytes that can outcompete seagrass for light and nutrients (Dennison et al. 1993, Hauxwell et al. 2001).

The effect of moderate nutrient loading on seagrass growing in oligotrophic waters is, however, less clear. In some situations, for example, there are positive correlations between seagrass biomass and nutrient loading, although most assessments have concluded that nutrient loading is more of a detriment than a benefit to seagrass ecosystems (see Ralph et al. 2006 for review). As seagrass systems become eutrophic, the top-down capacity of epibenthic herbivores to control epiphyte biomass, as well as factors that influence rates of herbivory (e.g. predation), become increasingly important in the resilience of seagrass ecosystems (Heck et al. 2006, Verhoeven et al. 2012). Resolving the relationship between nutrient loading and seagrass ecosystem health therefore requires an understanding of the responses of seagrass, epiphytes and grazers to sustained bottom-up forcing (York et al. 2012), as well as impacts to higher order predators and top-down controls (Heck \& Valentine 2007, Moksnes et al. 2008).

Where moderate nutrient enrichment enhances seagrass biomass, changes to associated faunal communities above and below the sediment surface may also occur. Enhanced seagrass and algal productivity stimulates secondary productivity (Nixon \& Buckley 2002), which can flow up food webs to higher order predators (Bishop et al. 2006), possibly even enhancing fisheries yields (Breitburg et al. 2009). In temperate seagrass ecosystems, bottom-up effects generally stem from consumption of epiphytes by mesograzers (Valentine \& Duffy 2006), which are in turn consumed by small fishes (Edgar \& Shaw 1995), with only a small proportion of seagrass biomass consumed by herbivorous or omnivorous fish (e.g. Bell et al. 1978) and grazing invertebrates (e.g. urchins; Larkum \& West 1990). Instead, most seagrass enters the sediment as detritus (Cebrian \& Lartigue 2004) where it modifies chemical and physical conditions and releases inorganic nutrients (e.g. compounds of nitrogen, phosphorous and potassium), as bacteria breakdown the particulate detritus and associated dissolved organic matter (Mann 1988). The detritus (Findlay \& Tenore 1982) or the micro-organisms fueled by its breakdown (Rublee 1982) are then consumed by detritivores and deposit-feeding organisms (Kelaher \& Levinton 2003, Kelaher et al. 2003). Concurrently, suspension-feeders actively filter algae and organic matter from the water column, thus contributing to nutrient recycling and benthic-pelagic coupling (Heip et al. 1995). Populations of depositfeeders, suspension feeders and detritivores, in turn, support benthic-feeding predatory fish and invertebrates (Klumpp et al. 1989, Edgar \& Shaw 1995).

An important step in resolving the relationship between waterborne nutrients and seagrass ecosystem dynamics is an experimentally derived understanding of bottom-up pressures on seagrass, epiphytes and associated above- and below-ground consumers. To improve understanding of these interactions, we conducted a manipulative field experiment to simultaneously evaluate the responses of seagrasses, epiphytes and the epiphyte- and the sediment-based seagrass food webs to moderate and high levels of nutrient enrichment. The experiment was done in an oligotrophic east Australian estuarine area (Scanes et al. 2007). In this low-nutrient environment, it was predicted that moderate nutrient loading would enhance seagrass and epiphytes, as well as above- and below-ground primary and secondary consumers. A higher loading was, however, predicted to initially enhance seagrass, epiphytes and above- and below-ground consumers, but over the longer term to negatively affect seagrass and epiphyte-based consumers as conditions became eutrophic. As seagrass declined, it was predicted that the quantity of organic carbon and quality of detritus in the sediment would increase and, in turn, would enhance populations of sediment-based organisms.

\section{MATERIALS AND METHODS}

\section{Study site and experimental design}

Experimental enrichments were done in Mullet Creek (3329' $\left.17^{\prime \prime} \mathrm{S}, 151^{\circ} 15^{\prime} 45^{\prime \prime} \mathrm{E}\right)$, a tributary of the Hawkesbury River, New South Wales (NSW), Australia, between August 2006 and April 2007. Mullet Creek runs through Brisbane Waters National Park, and has low ambient levels of ammonia $\left(\mathrm{NH}_{3}\right.$ : $\left.11.83 \mu \mathrm{g}^{-1}\right)$ and oxidized nitrogen $\left(\mathrm{NO}_{\mathrm{X}}: 3.99 \mu \mathrm{g} \mathrm{l}^{-1}\right)$ 
(York 2012). A comprehensive water quality sampling program of the broader Hawkesbury/Brisbane Water estuary found that $\mathrm{NH}_{3}$ and $\mathrm{NO}_{\mathrm{X}}$ concentrations in developed catchments may be 4.6 to 14.2 times greater in developed catchments compared to the undeveloped sites, such as Mullet Creek (Paterson et al. 2003, York et al. 2012). The experimental area at Mullet Creek had a dense cover of the seagrass Zostera muelleri with sparse and stunted blades of another smaller seagrass, Halophila ovalis. The $Z$. muelleri blades were colonized by a mixed assemblage of epiphytes typical for NSW (see Prado \& Thibaut 2008).

Fifteen $7 \mathrm{~m}^{2}$ sites covered with Zostera muelleri were selected at a similar depth (ca. $0.5 \mathrm{~m}$ water depth at mean low water springs) and assigned randomly to control, moderate or high nutrient enrichment treatments in a balanced design with treatment-control interspersion. Sites were separated by at least $10 \mathrm{~m}$ to ensure independence. At each site, there were 6 nutrient dispensers, arranged with one dispenser in the centre of the site, and the other 5 each spaced $1 \mathrm{~m}$ from the centre in a pentagon arrangement. Dispensers were constructed from $30 \mathrm{~cm}$ lengths of $5 \mathrm{~cm}$ diameter PVC pipe. Each was capped at both ends and had 96 holes (4 $\mathrm{mm}$ in diameter) to facilitate nutrient dispersion. Each dispenser was attached to the end of a $90 \mathrm{~cm}$ plastic stake that was pushed $60 \mathrm{~cm}$ into the sediment.

The nutrient dispensers in the moderate and high nutrient treatments were filled with 300 and $600 \mathrm{~g}$ of Osmocote $^{\mathrm{TM}}$ (Scotts), respectively. The dispensers in control sites were left empty. Osmocote ${ }^{\mathrm{TM}}$ is a granulated fertilizer that uses a biodegradable resin-coat to ensure a controlled release of inorganic nutrients, including nitrogen $(\mathrm{N})$, phosphorus $(\mathrm{P})$ and potassium compounds. It was important that the Osmocote $^{\mathrm{TM}}$ included a balance of nitrogen and phosphorus because under different conditions $\mathrm{N}$ and $\mathrm{P}$ can be limiting nutrients of seagrass growth (see Romero et al. 2006 for review). The Osmocote ${ }^{\mathrm{TM}}$ had an N:P ratio of 15:4 and the amount used in the high nutrient treatment represented $514 \mathrm{~g} \mathrm{~m}^{-2}$ and was based on the $500 \mathrm{~g} \mathrm{~m}^{-2}$ of Osmocote ${ }^{\mathrm{TM}}$ used by Heck et al. (2000) in a seagrass enrichment experiment on a similar scale. Although water retention rates and ambient nutrient loads can differ among locations, our experimental loading represented a substantially higher enrichment than reported rates of nitrogen loading in many coastal ecosystems around the world (Antón et al. 2011). To ensure a continuous supply of nutrients throughout the experiment, the Osmo$\operatorname{cote}^{\mathrm{TM}}$ in each dispenser was replaced every 2 mo.
The replacement rate was based on a pilot study at Mullet Creek that determined the average loss rate ( $\pm 1 \mathrm{SE}$ ) from dispensers filled with 500, 250 and $125 \mathrm{~g}$ over 6 wk was $25.0(0.3), 25.0(0.4)$ and $24.7(0.2) \%$, respectively.

\section{Sampling of macrophytes, epiphytes and the epiphyte-based food web}

To determine the diversity, abundance and biomass of predators in the epiphyte-based component of the food web (i.e. small fish that eat mesograzers), each site was sampled 1, 3, 5, 7 and 9 mo after the commencement of experimental enrichment. At each time, each site was surrounded with a $12 \mathrm{~m}$ seine net with $6 \mathrm{~mm}$ mesh. The 6 nutrient dispensers in the site were then removed and flagging tape was used to mark their position. The net was pulled over the site, holding both ends of the net to prevent fish escaping. After the sample had been taken, the dispensers were replaced and all fish were enumerated by species. Juvenile fish known to prey on grazing invertebrates were identified as per York et al. (2012), then dried with paper towel and weighed. To sample the above-ground Zostera muelleri biomass (hereafter called Z. muelleri biomass), blade surface area and length, as well as epiphytes and epiphyte-grazers, a $50 \mathrm{~cm}$ long $\times 20 \mathrm{~cm}$ diameter steel cylinder with a $500 \mu \mathrm{m}$ sieve at the top was randomly placed within each site 1, 3, 5, 7 and 9 mo after the commencement of experimental enrichment. A steel blade was passed through a bottom slit in the cylinder to cut the enclosed $Z$. muelleri just above the nodes. The cylinder was then inverted and all enclosed $Z$. muelleri, the attached epiphytes and associated invertebrates larger than $500 \mu \mathrm{m}$ were retained in the sieve. All material remaining on the sieve was preserved in a $7 \%$ formalin solution.

The preserved material from each $20 \mathrm{~cm}$ steel tube sample was sorted into Zostera muelleri blades and invertebrates. The epiphytes from 20 haphazardly chosen $Z$. muelleri blades were scraped off using a glass slide, with care taken not to destroy the leaf integrity. The surface area of the scraped $Z$. muelleri blades was calculated using a leaf surface area meter, which enabled the epiphyte load to be calculated as $\mathrm{g} \mathrm{m}^{-2}$ of $Z$. muelleri blades. After the first sampling, the length of 10 haphazardly chosen complete $Z$. muelleri blades was also measured from node to tip. The remaining non-seagrass material in the sample was washed over a $500 \mu \mathrm{m}$ sieve and the epiphyte-grazing invertebrates were enumerated 
after identification to the lowest possible taxon. The dry weights of $Z$. muelleri, epiphytes and epiphytegrazing invertebrates were determined by drying each sample at $60^{\circ} \mathrm{C}$ to constant weight. Although the relative change from wet to dry weight can vary among algal taxa (e.g. calcareous algae compared to filamentous algae), the epiphytic algae at Mullet Creek were dominated by filamentous, thallous and siphonaceous taxa with very little calcareous algae. There were also no apparent differences in the taxonomic composition of epiphytic algal assemblages among treatments. We did not conduct elemental carbon-nitrogen-phosphorus analysis of the seagrass and epiphytes because our observations of enhanced growth of seagrass and epiphytes in enriched as compared to control plots were alone strong evidence of effects of nutrient enrichment (Romero et al. 2006). Furthermore, ascertaining whether impacts of nutrient enrichment to consumers were a result of changes to producer biomass and/or palatability was beyond the scope of this study.

\section{Sampling of macrophytes and the sediment-based food web}

During the first 3 times of sampling, 1, 3 and 5 mo after the start of the experiment, a sediment core was extracted from directly underneath the $20 \mathrm{~cm}$ steel tube to collect seagrass rhizomes and roots, Halophila ovalis blades and sediment fauna. The aboveground $H$. ovalis biomass (hereafter called $H$. ovalis biomass) was collected from the sediment cores rather than with the steel tube used for Zostera muelleri, as the $H$. ovalis leaves were too stunted for the steel tube method to be effective. Each core was $15 \mathrm{~cm}$ in diameter and $10 \mathrm{~cm}$ deep. The sediment cores were sieved over a $1 \mathrm{~mm}$ mesh and the remaining rhizome and root material, $H$. ovalis blades and invertebrates were separated in a tray and the invertebrates preserved in a $7 \%$ formalin solution. The dry weight of $H$. ovalis blades and of total roots and rhizomes in each core was determined by drying to constant weight at $60^{\circ} \mathrm{C}$. The rhizome and root material was not analyzed by species because it was dominated by $Z$. muelleri biomass with only small amounts (an order of magnitude less) of $H$. ovalis. The remaining sediment-dwelling invertebrates were enumerated after identification to species or, when this was not possible, morphospecies was used. As per Bishop \& Kelaher (2013), the sediment-dwelling invertebrates were assigned to feeding guilds (i.e. deposit feeders/detritivores, grazers, suspension feed- ers or predators/scavengers) based on published information on their genera.

To determine whether nutrient enrichment influenced the percentage of organic carbon (\% C) or the carbon to nitrogen ratio ( $\mathrm{C}: \mathrm{N}$ ratio) of the sediment, two $5 \mathrm{~cm}$ diameter $\times 5 \mathrm{~cm}$ deep cores were taken from each site after 1 mo and after 9 mo from the start of the experiment. Sediments from cores were homogenized, and a subsample of each dried to a constant weight at $70^{\circ} \mathrm{C}$. As the sediments were silica-, not carbonate-based, acid treatment was not required prior to analysis. Approximately $0.2 \mathrm{~g}$ of each sample was ground to a fine powder for measurement of carbon and nitrogen composition using a CHN analyser (Leco TruSpec CN).

\section{Statistical analyses}

Non-parametric permutational multivariate analyses of variance (PERMANOVA; Anderson 2001) was used to test predictions about the effect of nutrient enrichment on seagrass, epiphytes and key components of the epiphyte-based and sediment-based food webs. For seagrass and epiphytes, the variables analyzed were the biomass, surface area and length of Zostera muelleri blades, the biomass of Halophila ovalis blades, and epiphytes on Z. muelleri blades and roots and rhizomes. For the epiphyte-based food web, the variables analyzed were grazer assemblage structure, richness, abundance and biomass and predator assemblage structure, richness, abundance and biomass. For the sediment-based food web, analyses were carried out on sediment \% C and C:N ratio, invertebrate assemblage structure and the total abundance of the functional groups (depositfeeders/detritivores, grazers, suspension feeders and predators/scavengers). The analyses of faunal assemblages were based on Bray-Curtis dissimilarity coefficients following a square root transformation. The analyses of univariate response variables were based on Euclidean distance.

As it was predicted that moderate nutrient loads would consistently enhance response variables but that high nutrient loads would initially enhance but then negatively affect response variables, PERMANOVA analyses included both the factors Treatment (controls, moderate and high enrichment) and Time since establishment. The predictions would initially be evaluated by testing the Time $\times$ Treatment interaction term and using post-hoc comparisons to examine the sources of treatment effects at each individual time of sampling. In the absence of interac- 
tion, a priori contrasts were carried out to test for differences among treatments in the main Treatment effect. Since samples were taken from different places within each site each time of sampling, this analysis structure was appropriate for all but one response variable. The exception was predators in the epiphyte-based component of the food web where the entire site was sampled each time. Hence, the data for this variable may have been temporally non-independent. To be conservative, the PERMANOVA analyses for predators in the epiphyte-based component of the food web utilized a repeatedmeasure design with 3 factors: Treatments (control, medium and high enrichment treatments), Time since establishment and Sites nested within Treatments. Pooling or term elimination was used where there were no significant differences among Sites (Trt) at $\mathrm{p}>0.20$ (Winer et al. 1991).

\section{RESULTS}

\section{Responses of macrophytes and epiphytes}

The total biomass and surface area of Zostera muelleri blades increased with the amount of nutrient experimentally added (Table 1, Fig. 1). Plots receiving the medium and high enrichment had 45 and $76 \%$ more seagrass biomass than control sites, respectively (Table 1, Fig. 1). In part, this was due to the greater length of $Z$. muelleri blades in nutrientenriched treatments than in controls (i.e. High =

Table 1. p-values from permutational multivariate analysis of variance (PERMANOVAs) comparing seagrass, algae, fish and invertebrates among treatments (Trt) with different nutrient loads (Control [C], Moderate [M] \& High [H]), among times of sampling (Ti) and among sites nested within treatments (Site (Trt)). 'Rhizomes \& roots' represents the combined below ground biomass of Zostera muelleri and Halophila ovalis. Bold: significant at $\alpha=0.05$. Full details of statistical analyses in Tables S1, S2 \& S3 in the Supplement at www.int-res.com/articles/suppl/m487p015_supp.pdf

\begin{tabular}{|c|c|c|c|c|c|c|c|c|c|c|c|c|}
\hline \multirow{3}{*}{ Primary producers } & \multicolumn{6}{|c|}{-Zostera muelleri } & \multirow{2}{*}{\multicolumn{2}{|c|}{$\begin{array}{c}\text { Halophila ovalis } \\
\text { biomass }\end{array}$}} & \multirow{2}{*}{\multicolumn{2}{|c|}{$\begin{array}{l}\text { Rhizomes \& } \\
\text { roots biomass }\end{array}$}} & \multirow{2}{*}{\multicolumn{2}{|c|}{$\begin{array}{l}\text { Epiphyte } \\
\text { biomass }\end{array}$}} \\
\hline & \multicolumn{2}{|c|}{ Biomass } & \multicolumn{2}{|c|}{ Blade SA } & \multicolumn{2}{|c|}{ Blade length } & & & & & & \\
\hline & $\mathrm{df}$ & $\mathrm{p}$ & $\mathrm{df}$ & $\mathrm{p}$ & $\mathrm{df}$ & $\mathrm{p}$ & df & $\mathrm{p}$ & df & $\mathrm{p}$ & df & $\mathrm{p}$ \\
\hline Treatment $=$ Trt & 2 & $<0.01$ & 2 & $<0.01$ & 2 & $<0.01$ & 2 & $<0.05$ & 2 & 0.77 & 2 & 0.10 \\
\hline C vs. M & 1 & $<0.01$ & 1 & $<0.01$ & 1 & $<0.01$ & 1 & 0.79 & 1 & 0.61 & 1 & $<0.01$ \\
\hline C vs. H & 1 & $<0.01$ & 1 & $<0.01$ & 1 & $<0.01$ & 1 & $<0.05$ & 1 & 0.84 & 1 & 0.10 \\
\hline M vs. $\mathrm{H}$ & 1 & $<0.05$ & 1 & $<0.01$ & 1 & $<0.05$ & 1 & $<0.05$ & 1 & 0.44 & 1 & 0.81 \\
\hline Time $=\mathrm{Ti}$ & 4 & $<0.01$ & 4 & $<0.01$ & 3 & $<0.01$ & 2 & 0.14 & 2 & $<0.05$ & 4 & $<0.01$ \\
\hline $\operatorname{Trt} \times \mathrm{Ti}$ & 8 & 0.49 & 8 & 0.31 & 6 & $<0.01$ & 4 & 0.24 & 4 & 0.76 & 8 & 0.13 \\
\hline \multicolumn{13}{|c|}{ Epiphyte-based component of food web } \\
\hline & \multicolumn{2}{|c|}{ Richness } & \multicolumn{2}{|c|}{$\begin{array}{l}\text { Grazer- } \\
\text { Abundance }\end{array}$} & \multicolumn{2}{|c|}{ Biomass } & \multicolumn{2}{|c|}{ Richness } & \multicolumn{2}{|c|}{$\begin{array}{l}\text {-Predator- } \\
\text { Abundance }\end{array}$} & \multicolumn{2}{|c|}{ Biomass } \\
\hline & df & $\mathrm{p}$ & df & $\mathrm{p}$ & $\mathrm{df}$ & $\mathrm{p}$ & $\mathrm{df}$ & $\mathrm{p}$ & df & $\mathrm{p}$ & $\mathrm{df}$ & $\mathrm{p}$ \\
\hline Treatment $=$ Trt & 2 & 0.75 & 2 & 0.69 & 2 & 0.80 & 2 & $<0.05$ & 2 & 0.08 & 2 & $<0.05$ \\
\hline C vs. M & 1 & 0.84 & 1 & 0.77 & 1 & 0.74 & 1 & $<0.05$ & 1 & $<0.05$ & 1 & $<0.01$ \\
\hline C vs. H & 1 & 0.38 & 1 & 0.35 & 1 & 0.64 & 1 & $<0.01$ & 1 & $<0.05$ & 1 & $<0.05$ \\
\hline M vs. $\mathrm{H}$ & 1 & 0.58 & 1 & 0.47 & 1 & 0.66 & 1 & 0.51 & 1 & 0.75 & 1 & 0.65 \\
\hline Time $=\mathrm{Ti}$ & 2 & $<0.01$ & 2 & $<0.01$ & 2 & 0.08 & 4 & $<0.01$ & 4 & $<0.01$ & 4 & $<0.01$ \\
\hline $\mathrm{Trt} \times \mathrm{Ti}$ & 4 & 0.68 & 4 & 0.71 & 4 & 0.60 & 8 & 0.15 & 8 & $0.986^{\mathrm{a}}$ & 8 & 0.37 \\
\hline Site (Trt) & & & & & & & 12 & 0.27 & 12 & $0.23^{\mathrm{a}}$ & 12 & 0.92 \\
\hline \multicolumn{13}{|c|}{ Sediment-based component of food web } \\
\hline & \multicolumn{2}{|c|}{$\begin{array}{l}\% \mathrm{C} \text { in } \\
\text { sediment }\end{array}$} & \multicolumn{2}{|c|}{$\begin{array}{c}\text { C:N ratio of } \\
\text { sediment }\end{array}$} & \multicolumn{2}{|c|}{$\begin{array}{l}\text { Deposit feeders } \\
\text { \& detritivores }\end{array}$} & \multicolumn{2}{|c|}{$\begin{array}{l}\text { Grazers in } \\
\text { cores }\end{array}$} & \multicolumn{2}{|c|}{$\begin{array}{l}\text { Suspension } \\
\text { feeders }\end{array}$} & \multicolumn{2}{|c|}{$\begin{array}{l}\text { Predators \& } \\
\text { scavengers }\end{array}$} \\
\hline & $\mathrm{df}$ & $\mathrm{p}$ & $\mathrm{df}$ & $\mathrm{p}$ & $\mathrm{df}$ & $\mathrm{p}$ & $\mathrm{df}$ & $\mathrm{p}$ & $\mathrm{df}$ & $\mathrm{p}$ & $\mathrm{df}$ & $\mathrm{p}$ \\
\hline Treatment $=$ Trt & 2 & 0.72 & 2 & 0.94 & 2 & 0.30 & 2 & 0.94 & 2 & 0.60 & 2 & 0.01 \\
\hline C vs. M & 1 & 0.43 & 1 & 0.83 & 1 & 0.14 & 1 & 0.69 & 1 & 0.61 & 1 & 0.15 \\
\hline C vs. H & 1 & 0.85 & 1 & 1.00 & 1 & 0.69 & 1 & 0.80 & 1 & 0.38 & 1 & $<0.01$ \\
\hline M vs. H & 1 & 0.46 & 1 & 0.38 & 1 & 0.17 & 1 & 0.91 & 1 & 0.48 & 1 & 0.13 \\
\hline Time $=\mathrm{Ti}$ & 2 & 0.12 & 2 & 0.13 & 3 & 0.55 & 3 & $<0.05$ & 3 & 0.69 & 3 & 0.41 \\
\hline $\operatorname{Trt} \times \mathrm{Ti}$ & 4 & 0.79 & 4 & 0.43 & 6 & 0.67 & 6 & 0.54 & 6 & 0.08 & 6 & 0.57 \\
\hline
\end{tabular}



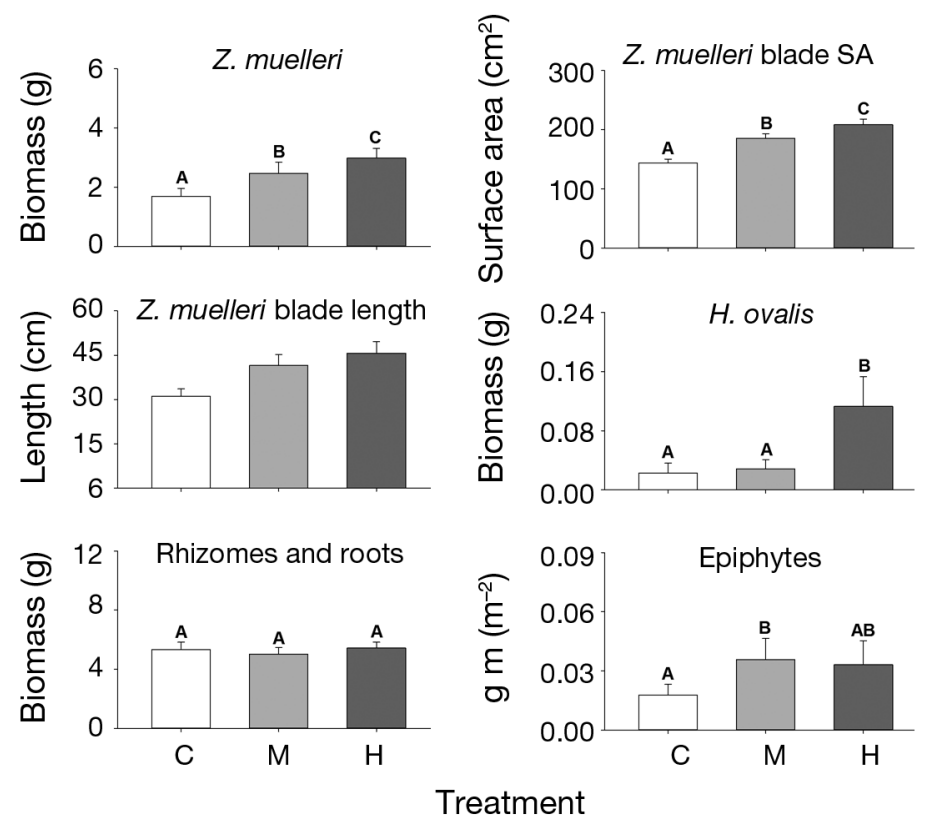

Fig. 1. Mean $( \pm 1 \mathrm{SE})$ biomass of seagrass and algae in control sites $\left(C_{i}\right.$ white bars) and those receiving moderate $\left(M_{\text {; }}\right.$

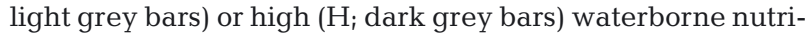
ent loads. As there was generally no significant interaction between time and nutrient treatment (Table 1), bars represent treatment averages across all sampling times and letters denote significant differences among treatments at $\alpha=$ 0.05. $\mathrm{n}=7$. Letters are not included for Zostera muelleri blade length because of a significant 'Treatment $\times$ Time' interaction

Medium > Control), a pattern which was statistically significant at each time of sampling except April 2007 (PERMANOVA post-hoc tests, significant Treatment $\times$ Time interaction, Table 1). The biomass of epiphytes on $Z$. muelleri blades was also greater in nutrient enriched treatments than in controls, although only the biomass in plots receiving medium nutrient loads statistically differed from controls (Table 1, Fig. 1). There was significantly more of the seagrass Halophila ovalis in the high enrichment sites than other treatments (Table 1, Fig. 1). The biomass of seagrass rhizomes and roots did not differ among treatments (Table 1, Fig 1).

\section{Responses in the epiphyte-based food web}

The assemblage of epiphyte grazers consisted of 5 gastropod, 1 opistobranch, 6 amphipod and 1 tanaid species. The structure of these grazer assemblages did not vary among treatments (PERMANOVA, Treatment: pseudo- $F_{2,60}=0.98, \mathrm{p}=0.45$ ) and there was no significant time by treatment interaction (Treatment $x$ Time: pseudo- $F_{8,60}=1.04, \mathrm{p}=0.30$ ). This was supported by the non-metric multidimensional scaling (NMDS) ordination which showed substantial overlap among the treatments (Fig. 2). The richness, abundance and biomass of epiphyte grazers were not affected significantly by nutrient enrichment (Table 1, Fig 3 ).

The assemblage of predators of epiphyte grazers consisted of 8 species of small juvenile fish (Acanthopagrus australis, Rhabdosargus sarba, Gerres subfasciatus, Pelates sexlineatus, Girella tricuspidata, Meuschenia freycineti, Monacanthus chinensis, Eubalichthys quadrispinis). The structure of grazer predator assemblages varied among treatments (Treatment: pseudo- $F_{2,60}=3.68, \mathrm{p}<0.01$ ) with the control treatments differing significantly from the 2 nutrient enrichment treatments (Control vs. Moderate: pseudo- $F_{1,60}=3.61, \mathrm{p}<0.01$, Control vs. High: pseudo- $\left.F_{1,60}=5.58, \mathrm{p}<0.01\right)$, which did not differ from one another (Moderate vs. High: pseudo- $F_{1,60}=$ $0.56, p=0.77$ ). A similar pattern of difference among enrichment treatments was seen for the richness, biomass and abundance of predators, with each of these variables significantly greater in nutrient-enriched than in control treatments throughout the experiment (Table 1, Fig 3).

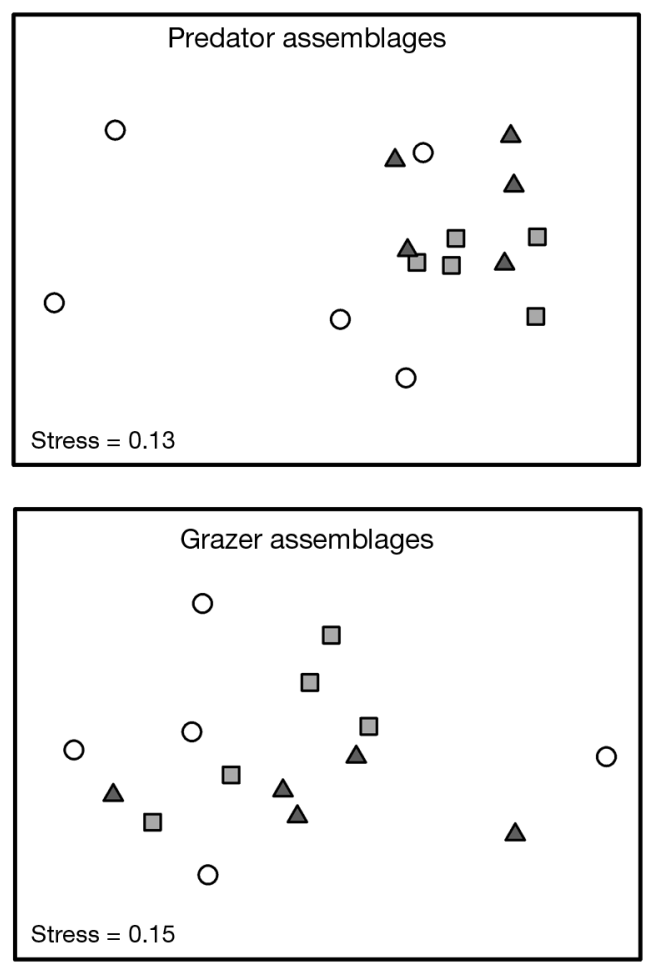

Fig. 2. Non-metric multidimensional scaling (NMDS) plots comparing assemblages of juvenile predatory fish and epiphyte grazers. (O) Control treatments; (ㅁ) moderate nutrient enrichment treatments; $(\Delta)$ high nutrient enrichment treatments. $n=7$ 


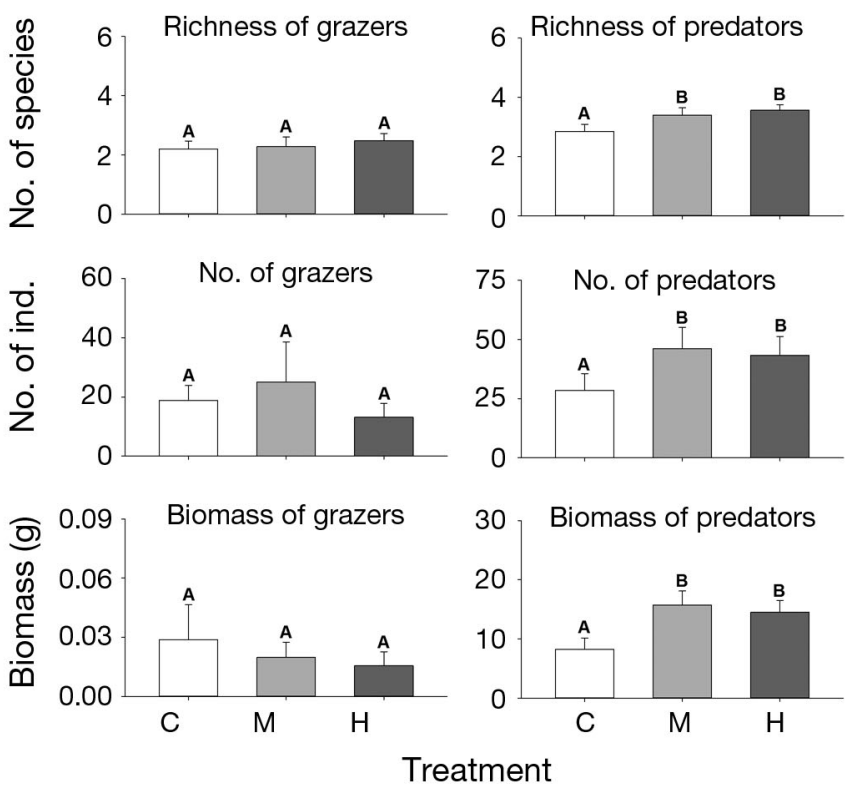

Fig. 3. Mean $( \pm 1 \mathrm{SE})$ richness, biomass and abundances of juvenile predatory fish and epiphyte grazers in control sites $(\mathrm{C}$; white bars) and those receiving moderate $(\mathrm{M}$; light grey bars) or high $\left(\mathrm{H}_{\text {; }}\right.$ dark grey bars) waterborne nutrient loads. Bars represent treatment averages across all sampling times and letters indicate significant differences among treatments at $\alpha=0.05 . \mathrm{n}=7$
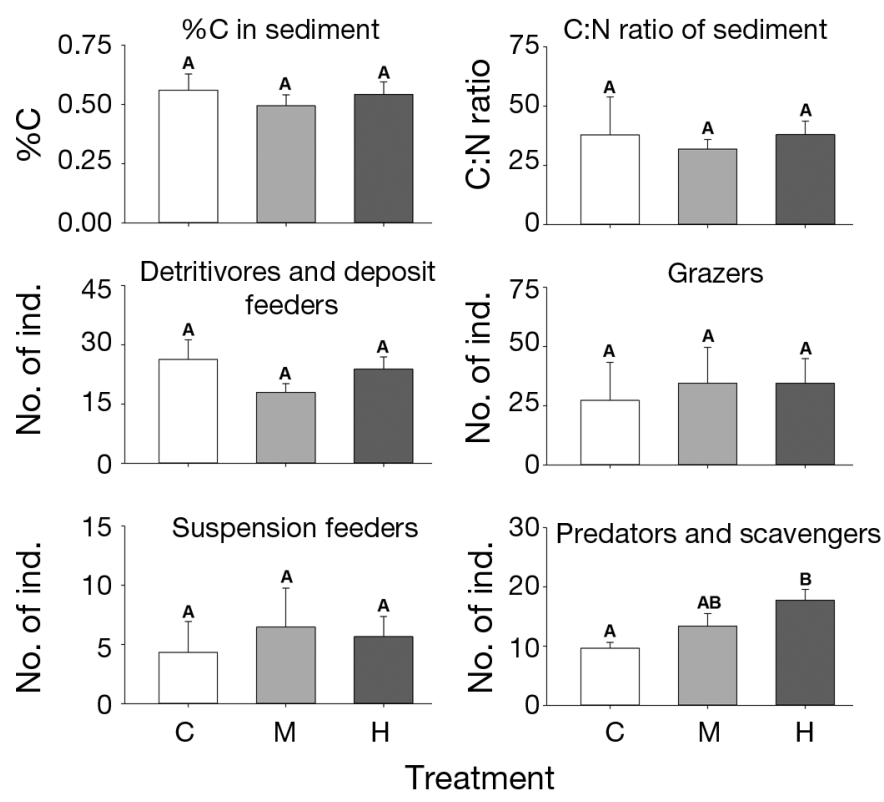

Fig. 4. Mean ( $\pm 1 \mathrm{SE})$ abundances of benthic macrofauna in control sites $\left(\mathrm{C}_{i}\right.$ white bars) and those receiving moderate

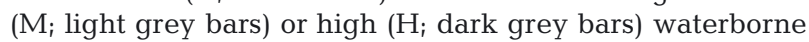
nutrient loads. Bars represent treatment averages across all sampling times and letters indicate significant differences among treatments at $\alpha=0.05 . \mathrm{n}=7$

\section{Responses in the sediment-based food web}

The percentage of organic carbon in the sediment and $\mathrm{C}: \mathrm{N}$ ratio did not differ significantly with nutrient enrichment (Table 1, Fig. 4).

The soft sediment macrofauna consisted of 48 species, dominated by gastropods, bivalves, mobile crustaceans and polychaetes. These species were divided into the 4 dominant functional groups, predators/ scavengers, grazers, detritivores/deposit feeders, suspension feeders and grazers, which were represented by 13, 23, 3 and 9 species, respectively. There were significantly more predators/scavengers in the high nutrient enrichment treatment than other treatments (Table 1, Fig. 4). There was no significant influence of waterborne nutrient enrichment on the abundance of deposit feeders/detritivores, grazers or suspension feeders (Table 1, Fig 4).

\section{DISCUSSION}

The Zostera muelleri-dominated seagrass ecosystem was affected significantly by the experimental nutrient enrichment. The principal changes were increased biomass of primary producers (Z. muelleri, Halophila ovalis and epiphyte loads) and secondary consumers in the epiphyte- and the sediment-based components of the seagrass food web. In contrast, primary consumers (epiphyte grazers, deposit feeders/detritivores, suspension feeders and grazers) did not respond significantly to the nutrient-enriched conditions. The responses of flora and fauna to nutrient enrichment were, in general, similar in medium and high enrichment treatments except that the increases in the biomass of seagrasses (i.e. Z. muelleri and $H$. ovalis) were greater in the sites with high compared to those with moderate enrichment.

The positive response of seagrass biomass to the experimental nutrient enrichment differs from negative responses reported in many studies of seagrasses around the world (see Ralph et al. 2006 and references therein). There are, however, published examples where seagrass biomass has correlated positively with nutrient availability, especially in situations where seagrass is nutrient-limited (e.g. Powell et al. 1989, Short et al. 1990). In such cases, experiments have shown that seagrasses respond positively to experimental nutrient enrichment by increasing photosynthetic performance, growth rates, leaf length, blade density and above-ground biomass (Agawin et al. 1996, Udy \& Dennison 1997a). Certainly, the greater biomass and blade length of Zostera muelleri 
in the nutrient-enriched treatments relative to controls suggests that nutrients may have been limiting growth of seagrasses in Mullet Creek. This result could have been further confirmed by more detailed measurements of seagrass productivity (e.g. net above-ground primary production or rates of leaf turnover) and changes in the elemental (CNP) composition of seagrass blades in control and enriched treatments, which were not included in this study.

Determining whether nutrient enrichment will have positive or negative effects on seagrass ecosystems depends on a range of factors, such as seagrassspecific physiological traits, grazing pressure, environmental conditions (e.g. water temperature, ambient nutrient loads, turbidity, sediment characteristics), natural disturbances and other anthropogenic stressors (e.g. industrial pollution). In the context of this study, the Zostera muelleri-dominated meadows were established in an area with low ambient nutrient loads associated with a relatively undeveloped catchment with infertile soils and a terrestrial management program specifically aimed at protecting the catchment from human disturbance (NPWS 1992). More broadly, it is accepted that estuaries in New South Wales are naturally nutrient poor (Harris 2001), with current loads being substantially lower than those reported for many parts of the world (Scanes et al. 2007). Given the oligotrophic estuarine conditions in the study area, the strong positive response of seagrasses and other primary producers to enrichment may well have resulted from nutrient limitation.

Reviews by Heck et al. (2006) and Antón et al. (2011) of experimental nutrient enrichments of seagrass systems using similar methods to our study demonstrate that the loading rates in our high nutrient enrichment treatment were likely to be much higher than those estimated for many estuaries around the world. The fact that such high nutrient load could have a positive influence on a seagrass ecosystem suggests that Zostera muelleri-dominated seagrass ecosystems in oligotrophic estuaries may be resilient to anthropogenic nutrient stress. In support of this contention, comparisons of the morphological characteristics of $Z$. muelleri meadows in anthropogenically enriched and relatively pristine areas of Morton Bay in Queensland (Udy \& Dennison 1997b), and the Brisbane Water, Pittwater and the lower Hawkesbury estuary in New South Wales (York 2012) did not find any clear correlation between nutrient levels and seagrass biomass, shoot density or blade length. Overall, this suggests that reasonable nutrient stress on its own is unlikely to be a major threat to $Z$. muelleri meadows in nutrient-poor waters.

Similar to broadscale field surveys of Brisbane Water, Pittwater and the lower Hawkesbury estuary (York et al. 2012), nutrient enrichment of the Zostera muelleri meadows at Mullet Creek resulted in elevated epiphyte biomass. While this pattern could be caused by enhanced nutrient availability for epiphyte growth, it may also have been caused by decreased grazing pressure. In temperate and subtropical systems, mesograzers play a pivotal role in directly facilitating seagrass through cropping of epiphytic algae (Gil et al. 2006, Valentine \& Duffy 2006, Baggett et al. 2010). Experimental studies of nutrient enrichment in seagrass systems that include mesograzers often find that grazing pressure explains more variation in the data than nutrient loading (Heck \& Orth 2006). Here, there was a non-significant trend for reduced biomass of mesograzers and more epiphytes in the enriched treatments compared to controls (Fig. 3).

Given the important role of mesograzers in controlling seagrass epiphytes (Valentine \& Duffy 2006, Baggett et al. 2010), processes that influence mesograzer biomass can play a key role in seagrass ecosystem dynamics (Heck et al. 2000, Baden et al. 2010). One possible explanation for the trend of reduced mesograzer biomass in the nutrientenriched plots might be that the value of epiphytes as a food resource decreased with enrichment. There was, however, no evidence for differences in epiphyte composition among plots. Furthermore, increased nutrient availability generally decreases the $\mathrm{C}: \mathrm{N}$ ratio of epiphytes, improving their quality as a food resource (Antón et al. 2011, Jaschinski \& Sommer 2011). A more probable explanation for the greater epiphyte and reduced mesograzer biomass in the nutrient-enriched plots was the enhanced numbers of predators in these areas. In this case, increased predation pressure on mesograzers may have indirectly enhanced epiphyte biomass by controlling grazing rates (Heck et al. 2000, Baden et al. 2010). Often, the indirect enhancement of epiphytes brought on by reduced grazing pressure negatively impacts the seagrass (e.g. Baden et al. 2010). In our experiment, however, both seagrass and epiphytic biomass were positively influenced by the nutrient enrichment treatments.

The elevated richness and abundance of predatory fish in nutrient-enriched treatments relative to controls may have resulted from bottom-up trophic transfer (Abrams \& Ginzburg 2000). Trophic modeling based on resource-dependent functional responses 
over 3 trophic levels predicts that sustained bottomup enrichment will lead to an increase in primary producers (epiphytes), no change in primary consumers (mesograzers) and a proportional increase in secondary consumers (juvenile predatory fish) (Ginzberg \& Akcakaya 1992). Based on significance tests, these predictions fit our results highlighting the potential for multiple trophic levels in seagrass ecosystems to change states in response to increased nutrient availability. To rigorously evaluate the efficacy of such a model, however, our experiment would have had to run for substantially longer than 9 months, because the model requires that organisms have sufficient time to equilibrate (Abrams \& Ginzburg 2000). Moreover, data would also have to be collected to ensure that the mortality rates of juvenile predatory fish did not vary systematically among treatments (e.g. differential predation rates from large piscivorous fish in control and enriched plots).

Enhanced habitat structure in nutrient-enriched plots compared to controls provides an alternative explanation for the greater abundance and biomass of juvenile predatory fish in the enriched treatments. Increasing biomass and surface area of seagrass can increase its value as a shelter by decreasing the effectiveness of predators (Heck \& Orth 2006). Here, the small juvenile fish that made up the mesograzer predator group may have received increased protection from large piscivorous fish in the nutrientenriched sites because there was significantly more seagrass in which they could shelter (Hindell et al. 2002). The difficulty with this explanation is that the additional protection provided by the enhanced seagrass surface area in the enriched plots would have to be scale-dependent; otherwise, the shelter benefits would apply similarly for both juvenile predatory fish and mesograzers. Although scale-dependent effects of habitat structure are common (e.g. Kelaher 2003), field sampling has often shown that both predators and mesograzers benefit from increased seagrass density and surface area (Heck \& Orth 2006 and references therein).

Despite increased biomass of primary producers (i.e. Zostera muelleri, Halophila ovalis and epiphytes) in the nutrient enrichment treatments, there was no evidence for increased organic carbon or nutritive quality of the detritus (i.e. reduced C:N ratio) in the sediment. In part, this could have been influenced by differences between leaf turnover rates and net primary production in controls and nutrient-enriched treatments, which were not measured in this study. For sediment systems, seagrass and algal detritus represent a key resource for deposit-feeding invertebrates (Bishop \& Kelaher 2007,2008 ) and nutrient cycling (Mann 2000). However, seagrass detritus is readily transported by water movements away from source populations (Taylor et al. 2010, Bishop \& Kelaher 2013). Given that quantity or quality of local sediment detrital resources were not enhanced by the experimental nutrient enrichment, it is not unexpected that neither the biomass of roots and rhizomes nor the abundance of depositfeeders was greater in nutrient-enriched sites relative to controls.

Similar to the epiphyte-based food web, there was evidence of bottom-up forcing enhancing the numbers of sediment-based secondary consumers in nutrient-enriched treatments. Resource-consumer models predict that bottom-up forcing will elevate the biomass of some or all of the mid-trophic levels in a complex food chain and cause a proportional increase in the biomass of apex predators (Abrams \& Ginzburg 2000, Bishop et al. 2006). In our study, enrichment by waterborne nutrients stimulated both above-ground and below-ground components of the seagrass food webs. Given that secondary consumers are often prey for economically-important larger fish and invertebrates (Hindell et al. 2002, Moksnes et al. 2008), the enrichment of Zostera muelleri meadows in oligotrophic conditions has the potential to enhance trophic linkages between seagrass ecosystems and coastal fisheries. Furthermore, because 7 of the 8 mesograzer predators enhanced by enrichment were juvenile fish of species that are targeted by commercial and recreational fisheries (i. e. Acanthopagrus australis, Rhabdosargus sarba, Gerres subfasciatus, Pelates sexlineatus, Girella tricuspidata, Meuschenia freycineti, Monacanthus chinensis; Rowling et al. 2010), the experimental enrichment may have also enhanced the nursery role of the $Z$. muelleri meadow, which is considered a key ecosystem service provided by seagrass (Heck et al. 2003, Antón et al. 2011).

Overall, this study demonstrates the potential for waterborne nutrients to positively influence aboveand below-ground components of seagrass ecosystems. Whether anthropogenic nutrient loading has a positive or negative effect on seagrass meadows and associated ecosystem services depends on specific traits of local seagrasses and other primary producers, top-down processes, ambient nutrient loads and other interactive anthropogenic stressors. In the context of this and other studies (e.g. Udy \& Dennison 1997b, York et al. 2012), it is probable that Zostera muelleri-dominated seagrass meadows in oligotrophic systems will be resilient to greater nutrient 
loads. As eutrophication is often concomitant with other anthropogenic stressors (e.g. non-nutrient pollutants in runoff and sewage discharge, foreshore development, overfishing, industrial pollution, invasive species and climate change), effective conservation strategies for $Z$. muelleri meadows will also need to consider the interactive impacts of nutrient enrichment and other key stressors.

Acknowledgements. We thank M. Cole, C. Shorter and M. Stranger for assistance with field work and sample processing. This study was funded by an Australian Research Council (ARC) Discovery Grant to B.P.K. and D.J.B. The experiments comply with the current laws of Australia.

\section{LITERATURE CITED}

Abrams PA, Ginzburg LR (2000) The nature of predation: prey dependent, ratio dependent or neither? Trends Ecol Evol 15:337-341

Agawin NSR, Duarte CM, Fortes MD (1996) Nutrient limitation of Philippine seagrasses (Cape Bolinao, NW Philippines): in situ experimental evidence. Mar Ecol Prog Ser 138:233-243

Anderson MJ (2001) A new method for non-parametric multivariate analysis of variance. Austral Ecol 26:32-46

Antón A, Cebrian J, Heck KL, Duarte CM, Sheehan KL, Miller ME, Foster CD (2011) Decoupled effects (positive to negative) of nutrient enrichment on ecosystem services. Ecol Appl 21:991-1009

Baden SP, Boström C, Arponen H, Tobiasson S, Moksnes PO (2010) Relative importance of trophic interactions and nutrient enrichment in seagrass ecosystems: a broadscale field experiment in the Baltic-Skagerrak area. Limnol Oceanogr 55:1435-1448

Baggett LP, Heck KL Jr, Frankovich TA, Armitage AR, Fourqurean JW (2010) Nutrient enrichment, grazer identity, and their effects on epiphytic algal assemblages: field experiments in subtropical turtlegrass Thalassia testudinum meadows. Mar Ecol Prog Ser 406:33-45

Barbier EB, Hacker SD, Kennedy C, Koch EW, Stier AC, Silliman BR (2011) The value of estuarine and coastal ecosystem services. Ecol Monogr 81:169-193

Bell JD, Burchmore JJ, Pollard DA (1978) Feeding ecology of 3 sympatric species of leatherjackets (Pisces, Monacanthidae) from a Posidonia seagrass habitat in New South Wales. Aust J Mar Freshw Res 29:631-643

> Bishop MJ, Kelaher BP (2007) Impacts of detrital enrichment on estuarine assemblages: disentangling effects of frequency and intensity of disturbance. Mar Ecol Prog Ser 341:25-36

> Bishop MJ, Kelaher BP (2008) Detrital species richness is less important than identity or mixing in determining macroinvertebrate assemblage composition. Oikos 117: 531-542

> Bishop MJ, Kelaher BP (2013) Replacement of native seagrass with invasive algal detritus: impacts to estuarine sediment communities. Biol Invasions 15:45-59

> Bishop MJ, Kelaher BP, Smith MPL, York PH, Booth DJ (2006) Ratio-dependent response of a temperate Australian estuarine system to sustained nitrogen loading.
Oecologia 149:701-708

Breitburg DL, Craig JK, Fulford RS, Rose KA, and others (2009) Nutrient enrichment and fisheries exploitation: interactive effects on estuarine living resources and their management. Hydrobiologia 629:31-47

Cebrian J, Lartigue J (2004) Patterns of herbivory and decomposition in aquatic and terrestrial ecosystems. Ecol Monogr 74:237-259

> Dennison WC, Orth RJ, Moore KA, Stevenson JC, and others (1993) Assessing water quality with submerged aquatic vegetation. Bioscience 43:86-94

> Duarte CM, Middelburg JJ, Caraco N (2005) Major role of marine vegetation on the oceanic carbon cycle. Biogeosciences 2:1-8

- Edgar GJ, Shaw C (1995) The production and trophic ecology of shallow-water fish assemblages in southern Australia. III. General relationships between sediments, seagrasses, invertebrates and fishes. J Exp Mar Biol Ecol 194:107-131

> Findlay S, Tenore K (1982) Nitrogen source for a detritivore: detrtius substrate versus associated microbes. Science 218:371-373

> Gil M, Armitage AR, Fourqurean JW (2006) Nutrient impacts on epifaunal density and species composition in a subtropical seagrass bed. Hydrobiologia 569:437-447

Ginzburg LR, Akcakaya HR (1992) Consequences of ratiodependent predation for steady-state properties of ecosystems. Ecology 73:1536-1543

Harris GP (2001) Biogeochemistry of nitrogen and phosphorus in Australian catchments, rivers and estuaries: effects of land use and flow regulation and comparisons with global patterns. Mar Freshw Res 52:139-149

Hauxwell J, Cebrián J, Furlong C, Valiela I (2001) Macroalgal canopies contribute to eelgrass (Zostera marina) decline in temperate estuarine ecosystems. Ecology 82: 1007-1022

Heck KL, Orth RJ (2006) Predation in seagrass beds. In: Larkum AWD, Orth RJ, Duarte CM (eds) Seagrasses: biology, ecology and conservation. Springer, Dordrecht, p 567-593

Heck KL, Valentine JF (2007) The primacy of top-down effects in shallow benthic ecosystems. Estuaries Coasts 30:371-381

Heck KL, Pennock JR, Valentine JF, Coen LD, Sklenar SA (2000) Effects of nutrient enrichment and small predator density on seagrass ecosystems: An experimental assessment. Limnol Oceanogr 45:1041-1057

- Heck KL Jr, Hays G, Orth RJ (2003) Critical evaluation of the nursery role hypothesis for seagrass meadows. Mar Ecol Prog Ser 253:123-136

> Heck KL Jr, Valentine JF, Pennock JR, Chaplin G, Spitzer PM (2006) Effects of nutrient enrichment and grazing on shoalgrass Halodule wrightii and its epiphytes: results of a field experiment. Mar Ecol Prog Ser 326:145-156

> Heck KL, Carruthers TJB, Duarte CM, Hughes AR, and others (2008) Trophic transfers from seagrass meadows subsidize diverse marine and terrestrial consumers. Ecosystems 11:1198-1210

Heip CH, Goosen NK, Herman PM, Kromkamp J, and others (1995) Production and consumption of biological particles in temperate tidal estuaries. Oceanogr Mar Biol Annu Rev 33:1-149

Hemminga MA, Duarte CM (2000) Seagrass ecology. Cambridge University Press, Cambridge

- Hindell JS, Jenkins GP, Keough MJ (2002) Variability in the 
numbers of post-settlement King George whiting (Sillaginidae: Sillaginodes punctata, Cuvier) in relation to predation, habitat complexity and artificial cage structure. J Exp Mar Biol Ecol 268:13-31

Hughes AR, Bando KJ, Rodriguez LF, Williams SL (2004) Relative effects of grazers and nutrients on seagrasses: a meta-analysis approach. Mar Ecol Prog Ser 282:87-99

> Jaschinski S, Sommer U (2011) How do nutrient conditions and species identity influence the impact of mesograzers in eelgrass-epiphyte systems? Mar Biol 158:193-203

Kelaher BP (2003) Changes in habitat complexity negatively affect diverse gastropod assemblages in coralline algal turf. Oecologia 135:431-441

Kelaher BP, Levinton JS (2003) Variation in detrital enrichment causes spatio-temporal variation in soft-sediment assemblages. Mar Ecol Prog Ser 261:85-97

Kelaher BP, Levinton JS, Hoch JM (2003) Foraging by the mud snail, Ilyanassa obsoleta (Say), modulates spatial variation in benthic community structure. J Exp Mar Biol Ecol 292:139-157

Kenworthy WJ, Wyllie-Echeverria S, Coles RG, Pergent G, Pergent-Martini C (2006) Seagrass conservation biology: an interdisciplinary science for protection of the seagrass biome. In: Larkum AWD, Orth RJ, Duarte CM (eds) Seagrasses: biology, ecology and conservation. Springer, Dordrecht, p 595-623

Klumpp DW, Howard RK, Pollard DA (1989) Trophodynamics and nutritional ecology in seagrass communities. In: Larkum AWD, McComb AJ, Shepard SA (eds) Biology of seagrasses. Elsevier, Amsterdam, p 394-457

> Larkum AWD, West RJ (1990) Long-term changes of seagrass meadows in Botany Bay, Australia. Aquat Bot $37: 55-70$

Mann KH (1988) Production and use of detritus in various freshwater, estuarine, and coastal marine ecosystems. Limnol Oceanogr 33:910-930

Mann KH (2000) Ecology of coastal waters with implications for management, 2nd edn. Blackwell Science, Oxford

McMahon K, Walker DI (1998) Fate of seasonal, terrestrial nutrient inputs to a shallow seagrass dominated embayment. Estuar Coast Shelf Sci 46:15-25

Moksnes PO, Gullström M, Tryman K, Baden SP (2008) Trophic cascades in a temperate seagrass community. Oikos 117:763-777

Nixon SW, Buckley BA (2002) 'A strikingly rich zone'Nutrient enrichment and secondary production in coastal marine ecosystems. Estuaries 25:782-796

NPWS (1992) Brisbane Water National Park plan of management. NSW National Parks and Wildlife Service, Sydney

> Orth RJ, Carruthers TJB, Dennison WC, Duarte CM (2006) A global crisis for seagrass ecosystems. Bioscience 56:987-996

> Paterson KJ, Schreider MJ, Zimmerman KD (2003) Anthropogenic effects on seston quality and quantity and the growth and survival of Sydney rock oyster (Saccostrea glomerata) in 2 estuaries in NSW, Australia. Aquaculture 221:407-426

Powell GVN, Kenworthy WJ, Fourqurean JW (1989) Experimental evidence for nutrient limitation of seagrass growth in a tropical estuary with restricted circulation. Bull Mar Sci 44:324-340

Prado P, Thibaut T (2008) Differences between epiphytic assemblages on introduced Caulerpa taxifolia and coexisting eelgrass (Zostera capricorni) in Botany Bay (NSW, Australia). Sci Mar 72:645-654

Ralph PJ, Tomasko D, Moore K, Seddon S, Macinnis-Ng CMO (2006) Human impacts on seagrasses: eutrophication, sedimentation, and contamination. In: Larkum AWD, Orth RJ, Duarte CM (eds) Seagrasses: biology, ecology and conservation. Springer, Dordrecht, p 567-593

Romero J, Lee K, Mateo MP, Mateo MA, Alcoverro T (2006) Nutrient dynamics in seagrass ecosystems. In: Larkum AWD, Orth RJ, Duarte CM (eds) Seagrasses: biology, ecology and conservation. Springer, Dordrecht, p 567-593

Rowling KA, Hegarty A, Ives M (2010) Status of fisheries resources in NSW 2008/09. Industry \& Investment NSW, Cronulla

Rublee PA (1982) Seasonal distribution of bacteria in saltmarsh sediments in North Carolina. Estuar Coast Shelf Sci 15:67-74

Scanes P, Coade G, Doherty M, Hill R (2007) Evaluation of the utility of water quality based indicators of estuarine lagoon condition in NSW, Australia. Estuar Coast Shelf Sci 74:306-319

> Short FT, Wyllie-Echeverria S (1996) Natural and humaninduced disturbance of seagrasses. Environ Conserv 23:17-27

Short FT, Dennison WC, Capone DG (1990) Phosphoruslimited growth of the tropical seagrass Syringodium filiforme in carbonate sediments. Mar Ecol Prog Ser 62: 169-174

Short FT, Carruthers T, Dennison W, Waycott M (2007) Global seagrass distribution and diversity: a bioregional model. J Exp Mar Biol Ecol 350:3-20

> Taylor SL, Bishop MJ, Kelaher BP, Glasby TM (2010) Impacts of detritus from the invasive alga Caulerpa taxifolia on a soft sediment community. Mar Ecol Prog Ser 420:73-81

Udy JW, Dennison WC (1997a) Growth and physiological responses of 3 seagrass species to elevated sediment nutrients in Moreton Bay, Australia. J Exp Mar Biol Ecol 217:253-277

> Udy JW, Dennison WC (1997b) Physiological responses of seagrasses used to identify anthropogenic nutrient inputs. Mar Freshw Res 48:605-614

Valentine J, Duffy JE (2006) The central role of grazing in seagrass ecology. In: Larkum WD, Orth RJ, Duarte CM (eds) Seagrasses: biology, ecology and conservation. Springer, Dordrecht, p 463-501

> Verhoeven M, Kelaher BP, Bishop MJ (2012) Epiphyte grazing enhances productivity of remnant seagrass patches. Austral Ecol 37:885-892

> Waycott M, Duarte C, Carruthers T, Orth RJ, and others (2009) Accelerating loss of seagrasses across the globe threatens coastal ecosystems. Proc Natl Acad Sci USA 106:12377-12381

Winer BJ, Brown DR, Michels KM (1991) Statistical principles in experimental design. McGraw-Hill, New York, NY

York PH (2012) Trophic dynamics in Australian seagrass beds: unraveling linkages from nutrients to fish. PhD thesis, University of Technology, Sydney

> York PH, Kelaher BP, Booth DJ, Bishop MJ (2012) Trophic responses to nutrient enrichment in a temperate seagrass food chain. Mar Ecol Prog Ser 449:291-296 